\title{
Entre o centro e a província: as elites e o poder legislativo no Brasil oitocentista
}

From the Center to the Provinces: Elites and the Legislative Power in 19th Century Brazil

\section{Miriam Dolhnikoff}

Professora do Departamento de História da USP e pesquisadora do Cebrap.

\section{Resumo}

0 artigo enfoca o processo de construção do Estado nacional brasileiro sob o arranjo institucional criado com o Ato Adicional de 1834, que definiu as competências do governo central e dos governos provinciais. Marcado pela tensão entre esses poderes e por conflitos de interesses entre as elites regionais, tal processo teve na Câmara dos Deputados um importante espaço de negociação. Ao reconstituir os debates parlamentares em torno da regulamentação da aposentadoria e da legislação tributária, entre outros, a autora analisa o papel do Poder Legislativo na conciliação dos interesses regionais e nacionais.

\section{Abstract \\ This article focuses on the Brazilian National-State building considering the institutional arrangement created by the "Ato Adicional" (Additional Act) which determined the central and provincial government competencies. Immersed on tensions among those two instances of power and on conflicts of interests that divided the regional elites, that process found in the Impe- rial Parliament one important arena of negotiation. By reconstructing the Parliament's debates on topics such as retirement and tax legislation, among others, the author analyses the role of the Legislative Power to level the national and regional interests.}

\section{Palavras-chave}

Império do Brasil, poder legislativo, elites, identidade regional, federalismo, debates parlamentares.

\section{Keywords}

Brazilian Empire, legislative power, elites, regional identity, federalism, parliamentary debates. 
Luiz Felipe de Alencastro. "O fardo dos bacharéis". Novos Estudos, № 19, 1987, p. 69.

Cf. Sérgio B. de Holanda. "A herança colonial: sua desagregação". In: - (org.). História geral da civilização brasileira. 6a ed.Tomo II. Vol.1 São Paulo: Difel, 1985 „ pp. 9-39; Maria Odila da S Dias. "A interiorização da metrópole". In: Mota, Carlos Guilherme (org.). 1822 dimensões. 2a ed. São Paulo: Perspectiva, 1986; José Murilo de Carvalho. A construção da ordem. Brasilia: UnB, 1981; Ilmar de Mattos. O tempo Saquarema. São Paulo: Hucitec, 1997.
0 papel estratégico da Câmara dos Deputados na definição das políticas nacionais tem raizes históricas, cuja compreensão fornece elementos importantes para analisar as relações entre Legislativo e Executivo no Brasil. Desde o século XIX, o Parlamento funcionou como espaço decisivo de negociação e confronto entre setores distintos da elite brasileira. A partir da Independência, afirma Luiz Felipe de Alencastro, "tanto a Assembléia Nacional como as câmaras municipais, e em seguida as assembléias provinciais, configuramse como os lugares privilegiados de conciliação entre as diferentes oligarquias regionais. No decorrer de quase dois séculos de história nacional, passando por todas as ditaduras e pelos diversos regimes constitucionais, pelas guerras e pelas insurreições, o país não conheceu mais do que uma quinzena de anos de interrupção das atividades parlamentares. Poucos Estados contemporâneos e muitos poucos Estados do Terceiro Mundo possuem uma experiência parlamentar comparável à do Brasil"1.

A construção do Estado nacional na América lusitana teve como um de seus principais eixos a disputa entre o projeto de unidade sob a direção do Rio de Janeiro, acalentado pelos grupos articulados ao aparato político lá instalado em 1808, e a resistência de elites provinciais ciosas de sua autonomia. Séculos de colonização haviam engendrado unidades político-administrativas que mantinham fracos vínculos entre si e demandavam autonomia para gerir seus interesses, sem a interferência de governos a elas externos, fosse o de Lisboa, fosse o do Rio de Janeiro. Ao mesmo tempo, os desafios postos à manutenção da ordem escravista, a transferência da Corte para a colônia e os acontecimentos a ela subseqüentes introduziam no panorama político a alternativa de unidade da América portuguesa em um único Estado. Dessa forma, a tensão entre unidade e autonomia das províncias acabou por marcar a história do país no século XIX2. A unidade sob a direção de um Estado com capacidade de defender os interesses escravistas só era aceitável para as elites provinciais, se no seu interior se garantissem autonomia para gerir suas provincias e participação na condução da política nacional.

Esse modelo foi concretizado a partir das reformas liberais da década de 1830, em especial o Ato Adicional de 1834, que estabeleceu a divisão constitucional das respectivas competências do governo central e dos governos provinciais. A efetiva participação das elites provinciais na organização do Estado nacional foi condição para a unidade, de modo a impedir que tendências centrifugas retalhassem a antiga Colônia em diversos países. Isso implicava a construção de um aparelho institucional, no qual essas elites contassem com autonomia para administrar suas províncias e, ao mesmo tempo, participassem do governo central, o que se daria por meio de suas representações na Câmara dos Deputados, onde não só defenderiam seus interesses específicos como influenciariam a política geral.

Assim, os debates parlamentares freqüentemente versavam sobre questões relevantes para a definição dos rumos do país, como as da escravidão e da propriedade da terra, e para a organização do Estado, como a legislação eleitoral, a elaboração do orçamento, a regulamentação dos efetivos militares etc. Cotidianamente, porém, pontos mais especificos mobilizavam as diversas bancadas e evidenciavam o exercício da conciliação, a exemplo dos casos da regulamentação da aposentadoria e da legislação tributária, em que nos deteremos mais adiante. A estabilidade do arranjo institucional derivava da sua capacidade de absorver os diversos conflitos em pauta.

A divisão territorial em províncias correspondeu à existência de governos que deliberavam unilateralmente sobre matérias de importância, com poderes que não poderiam ser revogados pelo Rio de Janeiro. A autonomia provincial incidia sobre a tributação, os empregos provinciais e municipais, as obras públicas e a força policial, de modo que os governos dispunham de capacidade financeira para decidir a respeito dos investimentos em áreas vitais para a expansão econômica, o exercício da força coercitiva e o controle de parte da 
"Apresentação do Ato Adicional à Regência pela Câmara dos Deputados para sua promulgação, 9 de agosto de 1834".

"Relatório que o ministro do Império José Joaquim Fernandes Torres apresentou à Câmara dos Deputados em 1867". máquina pública. Unidade e autonomia apareciam assim como dois elementos de um mesmo projeto nacional, conforme explicitou o ministro Limpo de Abreu ao entregar à Regência a versão final do Ato Adicional:

"Os objetos provinciais acham-se cautelosamente descritos e extremados para se evitarem destarte os conflitos e as lutas intermináveis que tão fatais podem ser aos interesses dos povos, comprometendo a sua paz e segurança; a unidade e a energia de ação, sem as quais o corpo social enlanguesce e definha, são conservadas no governo geral para poder preencher com vantagens do Estado as variadas e difíceis obrigações a seu cargo; o principio federal, amplamente desenvolvido, recebe apenas na sua aplicação aquelas modificações que são filhas do estudo e da experiência das nações mais cultas [...]. Releva, pois, que V. M. Imperial se digne de mandar promulgar esta lei de reforma, penhor da união das províncias, objeto dos votos e esperanças da nação a que preside, para que a sua execução faça sentir quanto antes todos os melhoramentos, e a par deles a prosperidade geral que promete e assegura"3.

"Penhor da união das províncias", a autonomia e a participação dos grupos provinciais, nas decisões gerais, eram consideradas imprescindiveis para a viabilização da unidade nacional. A revisão conservadora efetivada em 1840, por meio de uma interpretação do Ato Adicional, não alterou os fundamentos desse arranjo: promoveu a centralização do aparato judiciário, mas não incidiu sobre a divisão das competências tributária, legislativa e coercitiva. Assim é que em 1867 o ministro José Joaquim Fernandes Torres, importante líder conservador, exaltava as franquias provinciais como responsáveis pelo progresso e pela harmonia do pais:

"A instituição das assembléias provinciais, para substituírem os conseIhos gerais, era altamente reclamada pelas mais urgentes necessidades das províncias. Não sendo possivel que pelo poder central fossem pronta e devidamente apreciadas e atendidas tais necessidades, sofriam as mesmas provincias gravemente em seus interesses, e achavam-se peadas nas vias do progresso. Aquelas assembléias, investidas de todas as atribuições precisas para regular e satisfazer os interesses peculiares de cada uma das nossas grandes circunscrições administrativas dentro da esfera que se Ihes traçou, foram o complemento do sistema de nossas instituições e ao mesmo tempo um forte elemento da união e prosperidade do Império. É inegável o desenvolvimento que, depois de sua criação, têm tido nas províncias a instrução primária e secundária, as obras públicas, as vias interiores de comunicação, as prisões, as casas de trabalho e correção e muitos outros ramos do serviço público de sua competência, intimamente ligados ao progresso social. Se alguns desvios cometem essas assembléias no exercicio de suas funções, são de sobejo compensados pelos importantes beneficios que se Ihes devem"4.

Nesse processo, consolidou-se uma elite política provincial que se distinguia dos fazendeiros: enquanto estes permaneceram cuidando de seus negócios privados, aquela passou a se responsabilizar pela preservação do próprio Estado, mantendo profundos laços na organização socioeconômica da província, mas também comprometendo-se com a unidade e o Estado nacionais. Em algumas provincias, a autonomia gerou disputas armadas entre frações da elite, mas terminada a fase de consolidação do sistema, essas disputas passaram a se desenrolar no interior do arranjo institucional. Ao mesmo tempo em que os governos provinciais serviam à expansão dos interesses e conflitos, eles os canalizavam para o interior da máquina administrativa estatal, da qual faziam parte as próprias assembléias provinciais. Desse modo, o jogo político provincial passou a vincular-se a outro mais amplo.

Para exercer a autonomia em itens como tributação, coerção e legislação, os grupos dominantes nas províncias precisavam se organizar no interior do Estado e assumir determinados padrões de comportamento político. Fosse para atender a demandas específicas da região, fosse para satisfazer 
5

Esse procedimento permaneceu inalterado para a eleição de deputados provinciais mesmo quando se adotou o voto distrital para eleição dos deputados gerais, em 1855. Em 1875 o voto distrital foi abandonado e retomou-se o método anterior, que favorecia a representação provincial em detrimento do poder local. Pela nova lei, os eleitores votavam em tantos nomes quantos correspondessem a dois terços do número total de deputados da provincia. Desta feita, a alteração foi estendida à escolha dos deputados provinciais.

6

Cf. relatórios das câmaras municipais à

Assembléia Legislativa Provincial de São Paulo (1841-51) e anais da Assembléia Provincial de São Paulo (1848-49).

Posteriormente algumas provincias tiveram suas bancadas ampliadas, mas essa decisão não beneficiou a todas e tampouco atendeu ao critério da proporcionalidade plena. anseios generalizados, como o de controlar o poder provincial, esses grupos acabaram se envolvendo de fato na construção do Estado nacional e comprometendo-se com sua preservação. Sua prioridade era a expansão da economia de suas províncias, mas não como agentes diretos da elite econômica. A bancada gaúcha na Câmara, por exemplo, que diversas vezes se mobilizara para obter a diminuição de impostos gerais que prejudicavam a produção do charque, principal atividade do Rio Grande do Sul, não aceitou como solução a diminuição de impostos provinciais que também gravavam o produto. A bancada pernambucana, por sua vez, empenhou-se na defesa de impostos provinciais protecionistas que beneficiavam a indústria local de sabão, sem que esta necessariamente estivesse entre as principais demandas dos senhores de engenho de Pernambuco.

A diferenciação entre elite política e fazendeiros era reforçada pela própria legislação eleitoral. Os deputados provinciais eram eleitos pelo mesmo procedimento adotado para a escolha dos deputados da Assembléia Geral: cada eleitor deveria votar em tantos nomes quantos deputados houvesse na Assembléia Provincial. A razão para esse procedimento estava na preocupação com a formação de uma elite que transpusesse os limites locais. A obrigatoriedade de que cada eleitor escolhesse 36 nomes - ou 28, ou ainda 20, conforme o número de deputados que compunham a assembléia de sua província - impedia a eleição de fazendeiros com influência restrita a uma pequena localidade ${ }^{5}$. Somente aqueles com capacidade de obter votos nos mais diversos pontos da província, transcendendo o âmbito local, conseguiam se eleger. Foi o que ocorreu, por exemplo, nas eleições realizadas em dezembro de 1847 na cidade de Paranaguá, situada numa região então pertencente a São Paulo, e que a partir de 1853 se tornaria a província do Paraná: o candidato mais votado foi Antônio Francisco de Azevedo, da própria cidade, que não conseguiu se eleger porque não obteve votos em outras localidades, enquanto candidatos menos votados em Paranaguá, que não residiam nem tinham negócios na cidade, foram eleitos justamente porque somaram votos em diversas partes da província 6 . Forjava-se assim uma verdadeira representação provincial, no sentido assinalado de que apenas se tornavam deputados aqueles que exercessem influência política além dos limites dos seus municípios.

0 próprio exercício do governo da província completaria a formação dessa elite, já que os deputados não podiam governar tendo em vista apenas os interesses da sua localidade, sob pena de tornar inviável a administração provincial. Por isso, freqüentemente viriam a enfrentar demandas dos grandes proprietários e a adotar medidas que descontentariam alguns fazendeiros, mas que garantiriam o desenvolvimento da economia da província e, assim, a viabilidade do próprio governo.

Para que o novo arranjo institucional fosse fiador da unidade, era preciso que as elites provinciais reconhecessem nas suas bancadas um efetivo meio de defesa de seus interesses no interior do Estado, o que se evidencia no fato de que o número de deputados de cada província se tornou a medida do seu grau de influência na política nacional. A Constituição de 1824 determinara que uma lei regulamentar estabeleceria o critério para o número de deputados a que teria direito cada província, respeitada a proporcionalidade populacional. Essa lei, promulgada no mesmo ano, estabeleceu não um critério, mas números fixos: Minas Gerais daria vinte deputados; Bahia e Pernambuco, treze cada uma; Rio de Janeiro, doze; São Paulo, nove; Ceará, oito etc. Essa opção comprometia a proporcionalidade, uma vez que não se previa alteração do tamanho das bancadas, conforme a variação populacional das províncias no decorrer do tempo ${ }^{7}$.

As distorções, desse modo geradas, estiveram entre as causas da insatisfação da elite de São Paulo nas últimas décadas do Império. 0 número de deputados da província não acompanhou seu crescimento econômico e 
8

Anais da Assembléia Legislativa Provincial de São Paulo, 1840-41

Anais da Câmara dos Deputados, sessão de $11 / 02 / 1850$ populacional. Como se sabe, o descompasso entre representação política e importância econômica foi decisivo para a adesão dessa elite ao movimento republicano. As queixas paulistas evidenciavam a importância que as elites provinciais conferiam à sua representação na Câmara, razão para quererem ampliá-la. Se estavam descontentes nos anos finais do regime monárquico, nas décadas anteriores os paulistas reconheciam na sua bancada um instrumento de efetiva participação no jogo político nacional. Em representação enviada ao governo central em 1841, os deputados da Assembléia Legislativa de São Paulo, ao protestarem contra os rigores do recrutamento forçado para o exército nacional sofridos pela população da província, propunham que o número de recrutas fosse proporcional ao número de deputados de cada provincia na Assembléia Geral, sob o seguinte argumento:

"Sendo um princípio inegável de justiça que os ônus devem ser proporcionais às vantagens que se colhem do contrato social, e essas vantagens relativas à parte que cada uma das províncias toma na decisão dos negócios gerais, o que fica evidente pelo número de deputados que nomeia, parece que semelhante regra deve ser adotada como a mais justa"8.

A questão voltou à baila em 1850, quando foi discutido na Câmara dos Deputados o projeto que regulamentava o recrutamento para o Exército. Na ocasião, o deputado Paula Batista advertiu o ministro da Guerra sobre o perigo de não se respeitar a equivalência entre custo e benefício, que poderia estimular vocações separatistas:

"... a violação da igualdade neste caso [...] motiva desgostos e provoca ressentimentos [...]. Assim como a liberdade não consiste na excitação das paixões populares e nas licenciosidades que conduzem o país por entre os desfiladeiros de medonhos precipícios, assim também a ordem não consiste e nem pode consistir nessas parcialidades que contrastam a justiça, revoltam o bom senso, dão lugar a relutâncias e promovem desordens nos interesses de cada uma das provincias, que devem estar em harmonia com os interesses de toda a comunhão brasileira. Entre os principios de justiça e de ordem também avulta este: assim como todas as provincias participam dos gáudios e benefícios da comunhão, todas devem contribuir igualmente com sacrificios proporcionais às suas forças para a sustentação dessa mesma comunhão"9.

0 deputado expressava uma posição que não era só sua: da mesma forma que os limites da liberdade na sociedade de profunda exclusão social do Brasil do século XIX eram impostos pela necessidade de manter sob controle as "paixões populares", a imposição da ordem dependia da capacidade do Estado de obter legitimidade perante as elites provinciais, que a condicionavam ao atendimento de suas demandas.

A divisão de competência entre centro e província gerava inevitáveis conflitos e divergências de interpretações da legislação. Essas disputas podiam desembocar em tentativas de resolução fora da ordem legal, mas casos assim - dos quais o da Farroupilha é o exemplo mais significativo - foram exceções: em geral, as elites provinciais negociavam seus interesses por meio dos mecanismos institucionais. Em temas sensiveis, interesses provinciais e nacionais eram brandidos em intermináveis duelos sem que a estabilidade institucional fosse abalada. Tais contendas se concentravam no esforço do governo em obter, na Câmara dos Deputados, a revogação de leis provinciais que, alegava, extrapolavam a competência provincial e invadiam a esfera de ação reservada ao governo geral. Cabia ao Legislativo a decisão sobre a inconstitucionalidade das leis provinciais, o que tornava mais difícil ao governo central vencer os interesses provinciais. 0 Executivo encaminhava à apreciação do Conselho de Estado as questões sobre a constitucionalidade de determinadas leis provinciais. Diante de um parecer favorável do Conselho, o Ministério dos Negócios do Império orientava os presidentes das províncias a não sancionar projetos que versassem sobre aquele tema e, ao mesmo tempo, enviava o parecer à Câmara dos Deputados para deliberação. 0 poder de intervenção 
10

"Relatório da repartição dos Negócios do Império apresentado à Assembléia Geral Legislativa pelo ministro José Carlos Pereira de Almeida Torres em 1844".

11

Anais da Câmara dos Deputados, sessão de $12 / 05 / 1846$

12

Anais da Câmara dos Deputados, sessão de 07/05/1846 do Conselho de Estado e do Executivo era limitado, já que o veto presidencial podia ser derrubado por dois terços dos deputados provinciais. Cabia ao Parlamento a palavra final, e lá era preciso vencer a resistência de bancadas comprometidas com a defesa da autonomia dos governos de suas províncias.

\section{A questão das aposentadorias}

Um caso que exemplifica bem esse tipo de conflito é o da discussão em torno da concessão de aposentadorias, que ocupou várias sessões legislativas. 0 problema não aparecia como uma questão de direito trabalhista, mas como necessidade de um aparato institucional que estava sendo construído e precisava atrair indivíduos dispostos a se empregar no serviço público, de modo a se constituir uma burocracia estatal. Entre os itens transferidos pelo Ato Adicional para a esfera de competência das províncias estavam os empregos provinciais e municipais, e num contexto em que as eleições eram permanentemente fraudadas e manipuladas os empregos eram moeda politica de grande valor. Assim, os governos provinciais passaram a exercer com afinco a nova prerrogativa de criar cargos, nomear empregados, demiti-los, determinar seus salários e conceder aposentadorias. Essa última atribuição, contudo, era contestada pelo governo central, pois a aposentadoria era considerada uma mercê pecuniária, uma espécie de favor ou recompensa cuja concessão era privativa do governo central. Em 1844 o ministro dos Negócios do Império levantava o problema em seu relatório à Assembléia Geral:

"Algumas assembléias provinciais têm concedido pensões e aposentadorias a empregados públicos provinciais. Submetidas ao exame do Conselho de Estado as respectivas leis, julga ele que naquele procedimento excedem as mencionadas assembléias a órbita de suas atribuições, invadindo a dos poderes supremos do Estado. Quanto às pensões já o corpo legislativo tem manifestado a sua opinião, revogando algumas leis provinciais; outro tanto porém não acontece acerca das aposentadorias"10.

0 governo empenhava-se em obter na Câmara uma decisão que consagrasse o parecer do Conselho de Estado. No entanto, os deputados também sofriam a pressão das assembléias de suas províncias, até porque muitos deles haviam sido deputados provinciais e nessa condição legislado sobre aposentadoria. Em 1846, por exemplo, o deputado Carvalho e Silva justificava sua posição na Câmara afirmando que "pareceria muito censurável se, tendo sido autor de um projeto de aposentadorias quando deputado provincial do Ceará, não desse a essa casa uma satisfação do meu pensamento a respeito"11.

Em defesa de sua prerrogativa, as assembléias provinciais alegavam que as aposentadorias eram pagas pelos cofres da provincia e que deixar a decisão para o Executivo seria permitir que este tivesse ingerência sobre o orçamento provincial, o que não estava de acordo com o Ato Adicional nem com sua interpretação de 1840. Além disso, os governos provinciais tinham meios para impor obstáculos que tornariam a decisão letra morta, conforme salientava o deputado paraibano Toscano de Brito em 1846:

"Eu, membro da assembléia provincial, no momento em que visse a Assembléia Geral legislando a respeito de aposentadoria de empregados provinciais, certamente não daria dinheiro para isso, porque às assembléias provinciais compete distribuir o dinheiro da provincia"12.

Segundo a legislação em vigor, uma lei que regulasse a concessão de aposentadorias em todo o território nacional só seria possivel se estas fossem inteiramente custeadas pelo governo central, evitando-se assim que uma lei geral determinasse gastos provinciais. No entanto, ao governo central interessava apenas o poder de legislar sobre o assunto, não o ônus de arcar com suas despesas.

A autonomia provincial estava em jogo não apenas pela recusa da interferência do governo central nos gastos da província, mas também porque a concessão de aposentadoria era considerada necessária para garantir a leal- 
13

Idem.

14

Anais da Câmara dos Deputados, sessão de 13/05/1846. dade e continuidade de um corpo burocrático em constituição. Nesse sentido, o deputado Ferreira França, da Paraiba, alertava que:

"contestar esse direito às assembléias provinciais é colocá-las numa posição em que com dificuldade poderão achar pessoas hábeis que possam desempenhar certos empregos provinciais. Como será possivel que elas possam legislar sobre instrução primária sem oferecer àqueles que se encarregam dessa dificil tarefa uma vantagem no caso de dificuldade, de incapacidade não causada por ele? Vê-se pois que nesse caso as assembléias provinciais, que estão encarregadas da principal lei da educação primária da provincia, têm autoridade de declarar que aqueles que vão ocupar tais lugares terão uma recompensa dos sacrifícios que fazem e que fazem muitas vezes por um pequeno ordenado e a vantagem de uma aposentadoria"13.

A preocupação com a instrução pública, que pertencia à esfera de decisão e despesa dos governos provinciais, provavelmente não era prioritária para aqueles que se empenhavam em manter as aposentadorias no âmbito provincial: como a concessão era decidida caso a caso, a lealdade do funcionário público ficava garantida pela sua dependência aos deputados provinciais que decidiriam sobre sua futura aposentadoria, reforçando assim o clientelismo político no âmbito provincial. Por outro lado, não se deve desprezar o argumento de que a aposentadoria integrava o esforço de arregimentar trabalhadores para o serviço público, especialmente "pessoas hábeis" para o exercício dos cargos. No caso da construção de estradas, que constituíam uma das prioridades nos gastos provinciais, pois delas dependia o escoamento da produção para o porto, eram constantes nas assembléias de diversas províncias as queixas sobre a dificuldade de contratar engenheiros e outros trabaIhadores especializados.

Do ponto de vista prático, cabia ainda a questão sempre levantada de que as franquias provinciais eram uma condição para a eficiência do Estado, na medida em que o tornavam presente em todas as localidades. 0 Estado ainda não possuía uma máquina burocrática capaz de alcançar todo o território nacional de modo a centralizar decisões como as da aposentadoria, o que tornava imprescindivel sua descentralização, conforme salientou em 1846 o deputado José Antonio Marinho, de Minas Gerais:

"Entendo que seria muito perigoso, muito suscetivel de abusos, devolver ao poder geral tal atribuição, porque algumas provincias estão muito remotas da Corte. As pessoas interessadas nessas pensões, sendo geralmente pobres e desvalidas, não podem fazer valer na Corte os seus direitos para que o governo geral se compadeça de sua sorte, de maneira que aquelas que se achassem mais perto ou tivessem bons procuradores é que seriam atendidas e as mais necessitadas talvez seriam esquecidas"14.

Ao final de prolongados debates, os laços provinciais dos deputados gerais acabaram prevalecendo, de sorte que foi aprovado o projeto que reconhecia o direito das assembléias provinciais de legislar sobre a aposentadoria dos empregados públicos, sendo assim derrubado o parecer do Conselho de Estado.

Uma vez mantidas no âmbito provincial as decisões sobre as aposentadorias, estas, como as demais regras para o serviço público, variavam de província para província. Em geral não se condicionava a uma idade específica o momento em que o indivíduo faria jus a receber o benefício, mais freqüentemente concedido em razão da incapacidade efetiva de continuar cumprindo suas funções, fosse por velhice ou por impedimentos físicos. Mas também pesavam os anos de serviço prestados. A lei que regulamentava a aposentadoria em Alagoas, por exemplo, determinava que se o empregado, ao se aposentar, já tivesse vinte ou mais anos de serviço receberia o ordenado integral, enquanto os que contassem com menos tempo receberiam um montante proporcional aos anos trabalhados. Já no Rio Grande do Sul o direito era concedido ao empregado que, por idade ou enfermidade, estivesse 
15

Anais da Câmara dos Deputados, sessão de 07/05/1846

16

Idem. impossibilitado de continuar no cargo e que já tivesse vinte anos de serviço efetivo, deduzido o tempo das licenças tiradas. 0 valor da aposentadoria seria a metade do ordenado do servidor, não compreendidas as gratificações.

Os governos provinciais direcionavam parte dos rendimentos tributários para as despesas com os aposentados. Souza Martins, deputado em 1846, lamentava que aqui não houvesse, como na Inglaterra e na França, a regra de descontar do ordenado de cada empregado uma pequena porcentagem para formar um fundo destinado a pagar as aposentadorias:

"Entre nós tem-se seguido de tempo imemorial uma doutrina contrária. Julga-se que o governo é obrigado a pagar essas aposentadorias e, o que é mais para lastimar, sem regra, sem proporção com os anos de serviço nem com a qualidade do mesmo serviço, de modo que a tal respeito domina um completo arbitrio"15.

Uma possivel explicação para tal residiria na presença da escravidão. Enquanto na Inglaterra e na França se enfrentavam as profundas transformações trazidas pelo capitalismo industrial e a conseqüente necessidade de estabelecer em novas bases as relações trabalhistas, no Brasil esse problema era restrito ao Estado, que não podia contar com o trabalho escravo: era preciso criar um corpo de trabalhadores livres que, no processo de constituição do espaço público, atuasse de acordo com concepções modernas de relações de trabalho. Concepções modernas que não significavam a ausência de práticas tradicionais na concessão de beneficios, prevalecendo na maior parte das vezes a lógica do clientelismo. Segundo Souza Martins, a falta de uma legislação uniforme permitia os abusos e atos de corrupção que freqüentemente marcavam as concessões de aposentadorias pelas assembléias provinciais. Mas no seu entender essa não era uma razão para se lhes negar o direito de concedê-las:

"Só o tempo e a experiência do governo representativo é que podem ser corretivos de tais desvarios. Por conseqüência as assembléias provinciais podem abusar, mas por isso não Ihes devemos coatar a faculdade, o direito que têm de aposentar"16.

Na medida em que constituía tanto um mecanismo de atração de funcionários necessários ao Estado, quanto um importante instrumento de clientelismo político, o direito de concessão de aposentadorias foi acirradamente disputado pelos governos provinciais e central. Essa disputa foi travada no âmbito da Câmara dos Deputados e resolvida em favor das elites provinciais nela representadas. Em conseqüência, como já assinalado, as regras sobre aposentadoria, assim como todas as outras referentes a empregos provinciais e municipais, variariam de província para província, ao sabor das determinações do grupo dirigente local.

\section{"Guerra Fiscal"}

Os conflitos, no entanto, não opunham apenas províncias e centro. A herança colonial de regiões profundamente distintas entre si condicionava a unidade da América lusitana à capacidade do novo Estado de criar mecanismos de decisão sobre politicas gerais tendo em vista interesses provinciais conflitantes. Era o caso das verdadeiras guerras fiscais que tinham lugar na Câmara. Em 1850, por exemplo, houve acirrado debate em torno do requerimento apresentado pelo deputado baiano João Maurício Wanderley, o barão de Cotegipe, acerca da revogação de duas leis aprovadas pela Assembléia de Pernambuco que taxavam charutos, cigarros, tabaco, "bebidas espirituosas" e sabão vindos de outras províncias, de modo a proteger a produção local.

A bancada pernambucana mobilizou-se na defesa das leis protecionistas, enquanto as bancadas da Bahia e do Rio de Janeiro empenharam-se na sua revogação. Os argumentos de ambas as partes eram tanto legais quanto de ordem prática. Aqueles que queriam a revogação alegavam que as leis feriam o Ato Adicional ao taxar os produtos vindos de outras províncias, o 
17

Anais da Câmara dos Deputados, sessão de 23/05/1850.

18

Idem.

19

Idem.

20

Idem. que significaria, diziam, tributar a importação, direito exclusivo do governo central. Do ponto de vista prático, argumentavam que, ao adotar uma lei de caráter protecionista, Pernambuco prejudicava a produção das demais províncias. Por sua vez, os pernambucanos alegavam que para efeito de proibição de impostos provinciais a importação se referia apenas a produtos vindos do estrangeiro. De ordem prática, era o argumento sobre os efeitos negativos que a revogação da lei teria sobre o orçamento da província. Além disso, recusavam o que apontavam como uma injustiça, na medida em que em outras provincias estavam em vigor leis semelhantes sem que houvesse iniciativa da Câmara de revogá-las, inclusive leis que prejudicavam a aguardente e o açúcar pernambucanos. É exemplar nesse sentido o diálogo travado em plenário entre o deputado por Pernambuco Joaquim Vilella e o barão de Cotegipe.

"Essa questão não é de conveniência - alegava Vilella -, é uma questão toda de princípios, uma questão constitucional que não pode ser decidida pelos inconvenientes e prejuizos que a lei provincial de Pernambuco possa causar a esta ou aquela provincia. Assim, respeitando as boas intenções do nobre deputado autor do projeto, não posso supor que ele oferecesse esse projeto à consideração da Câmara unicamente porque entendesse que os interesses da província da Bahia eram ofendidos pela lei provincial de Pernambuco, sobre que versa o mesmo projeto; não por certo, porque a questão é de principios e não de interesse"17.

Cotegipe respondeu-Ihe reafirmando seu compromisso com os interesses baianos: "Eu sinto os efeitos da lei em minha província"18. Vilella procurou desqualificar o projeto justamente por ser expressão dos interesses provinciais, apesar de estar ele também empenhado na defesa de sua província:

"Pois, senhores, só havemos de revogar a lei de Pernambuco porque o nobre deputado pela Bahia, sentindo os efeitos dela em sua provincia, lembrou-se de propor na Câmara a revogação dela? E hão de ficar em vigor todas as outras idênticas que existem nas demais provincias, até que um ou outro deputado, por sentir os efeitos desta ou daquela na sua província, se lembre de propor a revogação daquela que de perto Ihe tocar?"19

Uma vez que as decisões sobre a inconstitucionalidade das leis provinciais cabiam ao Legislativo e não ao Judiciário, não se gerava jurisprudência, de modo que a revogação de uma lei de determinada provincia não incidia sobre lei semelhante de outra província. Isso exacerbava a autonomia provincial a ponto de em determinadas províncias permanecerem em vigência leis que haviam sido revogadas em outras. Cada elite provincial dependia assim da capacidade de sua bancada de fazer valer seus interesses na Câmara, o que foi explicitado por Cotegipe na discussão sobre a lei pernambucana:

"Dir-me-á o honrado deputado: por que não procurou igualmente de outros senhores deputados das diversas províncias análogos exemplares [de leis]? Respondo: porque o mal que a minha provincia sofre da imposição da lei de orçamento da provincia de Pernambuco data de muito tempo. [...] Pronto estou para revogar todas essas leis, mas encarregue-se o nobre deputado, como eu me encarreguei de apresentar a revogação desta, de propor a revogação das leis das outras províncias que ofendem os interesses da sua"20.

Em 1845 a bancada mineira estivera em situação semelhante, quando foi discutida a revogação de uma lei que taxava em quatro mil réis cada animal que entrasse em Minas Gerais transportando gêneros de províncias que não fossem limitrofes. Posicionaram-se contra a lei mineira os deputados do Mato Grosso e de Goiás, uma vez que suas províncias consumiam grande quantidade de produtos vindos do Rio de Janeiro, que necessariamente passavam por Minas e, em razão do imposto ali cobrado, chegavam ao mercado final com considerável aumento de preço. Na discussão que então se travou, o deputado goiano dom Manoel explicitou a dificuldade de se estabelecer um equilibrio entre a defesa de interesses provinciais e interesses nacio- 
Anais da Câmara dos Deputados, sessão de 09/04/1845.

22

José Murilo de Carvalho. Teatro das sombras: a política imperial. São Paulo: Vértice, 1988, p. 23.

23

Miriam Dolhnikoff. "Elites regionais e a construção do Estado nacional". In: Jancsó, István (org.). Brasil: formação do Estado e da nação. São Paulo: Hucitec, 2003, pp. 431-68. nais ao ponderar que a posição dos mineiros era "desculpável, porque cada um advoga a causa e os interesses de sua província", sustentando porém que, ao se tratar "de um artigo da Constituição e de remediar os males que estão sofrendo Goiás, Cuiabá e São Paulo, outro deve ser o nosso proceder"21.

Os deputados mineiros não tiveram sucesso, pois a lei de Minas acabou sendo revogada. Melhor sorte tiveram os pernambucanos, cujas leis protecionistas permaneceram em vigor. 0 pêndulo entre interesses provinciais e nacionais e entre demandas de ordem prática e prescrições legais oscilava de acordo com a capacidade de cada bancada de formar alianças, no interior da Câmara, a fim de obter maioria nas votações. Era o que acontecia na discussão do orçamento do Império. José Murilo de Carvalho observou que o Legislativo tinha grande poder de pressão sobre o Executivo por ser responsável pela aprovação do seu orçamento anual:

"O governo não podia funcionar legalmente sem que tal lei [do orçamento] fosse aprovada. Em caso de impossibilidade de aprovação, havendo dissolução, por exemplo, da Câmara, votava-se a prorrogação do orçamento do ano anterior para o seguinte. 0 ritual de discussão do orçamento era seguido com rigor e constituía arma poderosa na mão do Legislativo, que podia negar ao Executivo os meios de governar"22.

Portanto, nem mesmo o recurso à dissolução da Câmara abrandava a dependência do governo central na determinação dos recursos necessários ao exercício da governabilidade.

Nas discussões anuais sobre o orçamento era comum os deputados pressionarem para que nele fosse prevista ajuda financeira às suas respectivas províncias, alegando que os impostos provinciais não eram suficientes para cobrir todos os gastos necessários. Seu argumento era que a divisão tributária entre o governo geral e os provinciais favorecia aquele ao deixar para as provincias tributos de pouco rendimento. Mas se a divisão era desigual, isso não significava que as províncias não tinham meios para obter um rendimento significativo. Como procurei demonstrar em outro texto, os tributos arrecadados pelas províncias eram um instrumento efetivo nas mãos de suas elites para investir na expansão de suas economias ${ }^{23}$. Os constantes reclamos de insuficiência dos rendimentos provinciais tinham função retórica, com o objetivo de obter alocações de verbas para a província. Mas também expressavam o fato de que a divisão da competência tributária tinha o efeito de aprofundar as diferenças regionais pelo lado das despesas: na medida em que fazia depender dos recursos locais os investimentos no crescimento econômico, beneficiava as economias mais dinâmicas e penalizava as que encontravam dificuldades para a acumulação de riqueza. Existiram, é verdade, exceções. Em São Paulo, por exemplo, a autonomia tributária foi vital para que o governo da província criasse as condições de infra-estrutura que permitiram a expansão da cafeicultura, transformando a secundária província na região mais rica do país. No geral, porém, a ausência de uma política nacional que procurasse compensar com investimentos do governo central as desigualdades regionais resultou no aprofundamento destas.

Além do interesse mais genérico em diminuir as despesas e aumentar as receitas provinciais, havia os interesses específicos que mobilizavam determinadas bancadas na discussão do orçamento geral. Era o caso, por exemplo, dos deputados do Rio Grande do Sul, que constantemente procuravam alterar o orçamento de modo a eliminar impostos que consideravam prejudiciais à produção do charque. Assim, na discussão do orçamento, em 1846, o deputado Vieira Cunha requisitava que fosse livre de direitos o charque exportado para o estrangeiro:

"Todos nós sabemos que depois dos últimos acontecimentos em Montevidéu e Buenos Aires o comércio de Havana, que para ali se dirigia, está hoje encaminhado para a minha provincia, e como receio que, melhorando o estado daquelas repúblicas, passe esse comércio outra vez para [elas], 
24

Anais da Câmara dos Deputados, sessão de 22/06/1846

25

Anais da Câmara dos Deputados, sessão de 28/02/1850 lembro-me de mandar esta emenda com o fim de promover a sua conservação na província do Rio Grande. Quando o comércio de Havana estava encaminhado para o Rio Grande o governo estabeleceu o direito de 6\% sobre o charque que dali se exportava, donde resultou que os navios que se dirigiam ao Rio Grande deixaram de lá ir e foram para Montevidéu, vindo assim a sofrer grande prejuizo a provincia"24.

A especificidade da economia gaúcha, tanto no tocante à natureza de sua atividade (a produção de charque para o mercado interno) quanto à concorrência que sofria da produção uruguaia e argentina, tornava alguns impostos gerais prejudiciais para o Rio Grande do Sul, entre os quais aquele que incidia sobre o sal importado para a produção do charque. Em 1850 o deputado rio-grandense Cruz Secco assim defendia a emenda ao orçamento que ele apresentava no sentido de diminuir essa taxação:

"Creio, sr. presidente, que ninguém poderá contestar a justiça desta emenda, porque sendo unicamente o sal estrangeiro que pode servir para a salga de carnes e couros necessariamente deve ser considerado nas charqueadas como matéria-prima, e tendo sido diversas leis promulgadas em beneficio de outras fábricas, abolindo o imposto que deveriam pagar as matérias-primas que nelas se empregassem, igual disposição deveria ter sido promulgada a respeito do sal estrangeiro importado na província do Rio Grande do Sul para as fábricas ali existentes. Assim porém não tem acontecido, apesar de diversas representações que têm sido dirigidas em diferentes épocas à Assembléia Geral pela Assembléia Provincial, pedindo que se extinguisse esse imposto"25.

0 deputado apresentava as dificuldades enfrentadas pela produção gaúcha diante da concorrência com o charque uruguaio no mercado brasileiro, que só poderia ser vencida com a isenção fiscal para o sal importado, de modo a baratear o produto nacional. Fernandes Chaves, também do Rio Grande do Sul, fundamentava as pretensões gaúchas com o argumento de que no Uruguai a importação do sal estava isenta da cobrança de direitos alfandegários, o que tornava o preço desse concorrente mais baixo do que o do produto fabricado no Rio Grande do Sul. A reivindicação protecionista voltava-se também para os tributos cobrados sobre o charque uruguaio que entrava no pais, cujo aumento beneficiaria o produto rio-grandense:

"Eu também tencionava apresentar outra emenda elevando pelo menos a 35\% o imposto que pagam as carnes secas estrangeiras que são importadas no Império [...]. Precisam as charqueadas do Rio Grande algum favor a fim de poderem as carnes secas nela fabricadas entrar em concorrência com as que se importam no império dos Estados vizinhos, onde [...] o gado custa muito menos. Não é seguramente um imposto de 25\% somente que poderá fazer desaparecer a impossibilidade de concorrência"26.

Derrotada a Farroupilha, a elite gaúcha, assim como as das demais províncias, encontrava na Câmara um espaço decisivo para negociar seus interesses especificos. 0 sucesso de cada uma dependeu da capacidade de sua bancada de conquistar o apoio da maioria, o que talvez explique o fato de o deputado Cruz Secco ter desistido de apresentar a emenda para o aumento do imposto sobre o charque uruguaio. Por se tratar de um produto destinado à alimentação dos escravos, interessava às elites das regiões com grande número de cativos manter o charque barato e, portanto, não onerar com impostos aquele vindo do Uruguai. Essa estratégia fica explicitada na fala do deputado Fernandes Chaves:

"É preciso fazer alguma coisa para animar a indústria do fabrico das carnes do Rio Grande do Sul. Ora, parece-me que para aumentar-se os direitos sobre as carnes estrangeiras talvez isso fosse em prejuizo das provincias do Norte, as quais sem dúvida quererão ter essa matéria por preço mais cômodo. Julgo, pois, que se podia conseguir o mesmo fim isentando-se de direitos a matéria-prima [...] necessária para essa manufatura, que é o sal27. 
28

Anais da Câmara dos Deputados, sessão de 01/03/1850.

29

Guilherme Deveza. "Política tributária no período imperial". In: Holanda, Sérgio B. de (org.). História geral da civilização brasileira. 4a ed.Tomo II. Vol. 4. São Paulo: Difel, 1985.

30

Anais da Câmara dos Deputados, sessão de 14/05/1850.

31 Idem.

32

Idem.
A disposição dos deputados rio-grandenses para a negociação não foi porém suficiente, pois enfrentaram a reação dos representantes de províncias produtoras de sal, que entendiam ser o imposto importante para proteger sua produção, bem como daqueles cujas províncias não eram prejudicadas pelo tributo, e por isso tendiam a assumir a defesa dos rendimentos provenientes desse imposto para os cofres gerais. Tal foi a posição expressa pelo deputado Francisco Vianna, do Rio de Janeiro, ao afirmar seu voto contra a isenção de imposto para o sal importado, pois isso significaria

"desfalcar-se a renda abolindo-se a que produz o sal importado do estrangeiro, que não é pequena, [e] se há entre nós indústria que deva ser protegida é a do sal, de que, segundo me informam, abundam o Maranhão, o Rio Grande do Norte e o Rio de Janeiro em Cabo Frio"28.

Como notou Guilherme Deveza, um dos fatores da ineficiência das tentativas de implementar taxas alfandegárias de caráter protecionista relacionava-se ao fato de que o grosso da arrecadação do governo central se concentrava no comércio externo, o que gerava uma tensão entre os interesses fiscais, os interesses da agricultura de exportação e as demandas protecionistas. Estas últimas implicavam justamente a isenção de matérias-primas destinadas à manufatura nacional e a conseqüente queda da arrecadação fiscal sobre a importação, que só podia ser compensada onerando-se a exportação, o que contrariava as elites que extraíam sua riqueza dessa atividade ${ }^{29}$.

A especificidade da economia gaúcha tornava a elite rio-grandense minoritária na reivindicação da isenção sobre o sal, em detrimento de suas tentativas de incluí-la no orçamento. Assim é que, conforme os argumentos dos deputados contrários à sua reivindicação, se as charqueadas do Rio Grande do Sul se ressentiam da concorrência uruguaia, o problema deveria ser resolvido no âmbito provincial, sem onerar as outras províncias. la nesse sentido o posicionamento do deputado pernambucano Henriques de Rezende:

"Quando a Assembléia Provincial, depois de esgotar os meios ao seu alcance para proteger essas fábricas da provincia, conhecesse que eles eram insuficientes, reclamaria então algum favor da Assembléia Geral. Se a Assembléia Provincial quer proteger as fábricas do Rio Grande do Sul, deve começar suprimindo o imposto de oitenta réis sobre arroba de carne, pois quer aumentar a imposição em beneficio de seu cofre e que sofra a renda geral"30?

0 mesmo argumento foi lançado pelo ministro da Marinha, que se encontrava em plenário, ao afirmar que a solução "para que os charques pudessem concorrer no mercado com o estrangeiro seria a abolição do imposto provincial que pesa sobre a carne, imposto que importa em uma soma muito maior"31. A resposta do deputado Cruz Secco evidenciava o dilema entre interesses provinciais e gerais, ao defender o tributo provincial como condição para garantir entradas suficientes para que a província fizesse frente às suas despesas:

Eu perguntarei ao nobre ministro donde tiraria a Assembléia Provincial renda para satisfazer as suas despesas? Devia subsistir a provincia sem renda alguma provincial? Como cumprir as disposições do Ato Adicional que mandam que as assembléias provinciais decretem a força de polícia etc. ${ }^{32}$ ?

As imposições sobre a produção eram uma importante fonte de arrecadação para as provincias, da mesma forma que as taxações sobre a importação para o governo central. Ambas pesavam sobre a produção do charque, e tratava-se de decidir que cofre perderia recursos para se proteger a indústria gaúcha. Os governos provinciais procuravam proteger seus rendimentos e ao mesmo tempo sua produção, objeto preferencial da tributação provincial, pressionando pela diminuição dos impostos gerais que sobre ela incidiam, sem abrir mão dos impostos provinciais que a oneravam. Não atuavam pois, como meros representantes da elite econômica provincial, mas como represen- 
tantes do governo provincial, a quem interessava não apenas a expansão da economia, mas também a preservação da sua capacidade arrecadadora.

0 perfil do Estado desenhado a partir do Ato Adicional determinou a regionalização do jogo político, num arranjo que impunha a constante negociação entre governos provinciais e governo central e entre as próprias elites das diversas províncias. Beneficiados pela aquisição de capacidades tributária, legislativa e coercitiva, os grupos provinciais acabaram se envolvendo na construção do Estado nacional. A tônica de sua participação foi a conciliação com o governo do Rio de Janeiro, que teria lugar privilegiado nas assembléias provinciais e na Câmara dos Deputados. Conciliação no sentido de aceitar uma ordem institucional no interior da qual o conflito de interesses das províncias entre si e com o centro era reconhecido, e que previa mecanismos para resolvê-los sem colocar em risco a continuidade dessa ordem. Uma vez que o espaço de negociação entre os diversos interesses era a Câmara, apenas aqueles que conseguiam firmar alianças para obter maioria podiam impor suas demandas. Essas alianças eram em geral conjunturais e determinavam diferentes vencedores e perdedores a cada passo. As elites provinciais tiveram, desse modo, papel fundamental na construção do Estado e na configuração de sua dinâmica, influindo decisivamente na sua condução. Institucionalmente, portanto, as decisões políticas sempre tiveram de se adequar, de alguma forma, às demandas e capacidade de pressão dessas elites. Esse era o preço a pagar pela unidade da América lusitana sob a hegemonia de um único Estado. 